\title{
Projekt Krtek v síti
}

\section{Project The mole in the network}

\author{
Tomáš Vyhlídal, Kateřina Holická, Ondřej Ješina \\ Fakulta tělesné kultury, Univerzita Palackého, Olomouc, \\ Česká republika
}

\section{Abstrakt:}

Př́spěvek seznamuje laickou i odbornou veřejnost s projektem Krtek $v$ síti. Tento projekt je zaměren na podporu komplexní péče o děti s onkologickým onemocněním, jejich sourozence a rodiče. Hlavním cillem projektu je vytvoření sítí organizací na úrovni neziskových organizací, školských a zdravotnických organizací a vysokých škol, zabývajicich se zvyšováním kvality života dětí s onkologickým onemocněním během léčby a po jejím ukončení. Bude vytvořen systém spolupráce na úrovni Nadačního fondu dětské onkologie KRTEK (Česká republika), Univerzity Palackého v Olomouci (České republika) a sdružení Rady mládeže Žilinského kraje (Slovenská republika). Pomocí česko-slovenské spolupráce chceme vytvořit unikátni systém výměnných pobytových programů zaměrených na aplikované pohybové aktivity, kde se budou děti s onkologickým onemocněním, jejich rodiče i sourozenci České a Slovenské republiky společně setkávat a absolvovat tyto programy pod odborným vedenim.

\section{Abstract:}

The allowance introduces the lay and professional public project The mole in the network. This project aims at support the comprehensive care of children with oncological disease, their siblings and parents. The chief aim of the project is to create networks of organizations at the level of nonprofit organizations, educational and health organizations 
and universities that deal with improving the quality of life of children with oncological disease during and after treatment. It will be created a system of cooperation at the level of Endowment fund pediatric Oncology KRTEK (Czech Republic), Palacky University in Olomouc (Czech Republic) and the Regional youth council of Žilina (Slovak Republic). With the czech-slovak cooperation we want to create an unique system of exchangeable residential programs aimed at adapted physical activity where the children with oncological disease, their parents and siblings from the Czech and Slovak Republic will meet together and attend the programs under professional guidance.

Klíčová slova: Aplikované pohybové aktivity, onkologické onemocnění, systém podpory.

Key words: Adapted Physical Activity, oncological disease, system of support.

Tento př́spěvek vznikl v rámci projektu KRTEK V SÍTI, č. 22410220037.

\section{ÚVOD}

Projekt KRTEK V SÍTI je projektem přeshraniční spolupráce SR-ČR zabývající se problematikou onkologického onemocnění dětí. Projekt je realizován v př́hraničních regionech České a Slovenské Republiky. V ČR se jedná o kraje: Jihomoravský, Zlínský, Moravskoslezský. V SR o kraje: Žilinský, Trnavský, Trenčínský. Hlavním řešitelem projektu je Nadační fond dětské onkologie KRTEK, spoluřešiteli projektu jsou Univerzita Palackého v Olomouci (Katedra aplikovaných pohybových aktivit, Fakulta tělesné kultury) a Rada mládeže Žilinského kraje. Onkologické onemocnění je obrovskou zátěží nejen na fyzickou, ale i na psychickou a sociální stránku dítěte a jejich nejbližšího sociálního okolí. Dlouhodobá léčba znemožňuje pacientům školní docházku, běžné dětské aktivity a kontakty. Děti trpí mimo narušení vlastní emocionální rov- 
nováhy také ztrátou sociálních kontaktů a druhotně často sociálním odloučením celé rodiny. $Z$ těchto důvodů se bude projekt pomocí cílených aktivit, které mají pozitivní vliv na všestranný rozvoj osobnosti dítěte i rodičů, snažit o zlepšení kvality života této specifické skupiny během léčby a po léčbě. V současné době chybí v cílových regionech, kterých se projekt dotýká (Jihomoravský, Moravskoslezký, Zlínský, Trnavský, Trenčínský, Žilinský) systematická podpora pro znovuzačlenění dětí s onkologickým onemocněním do školního i mimoškolního prostředí. Chybí informovanost pedagogických, zdravotnických a dalších pracovníků profesně aktivních v oblasti problematiky onkologického onemocnění a podpory zdraví a zvýšení kvality života $\mathrm{s}$ využitím pohybových aktivit. Chybí systematické propojení teorie a praxe a vznik sítě organizací mající vliv na zvyšování kvality života této cílové skupiny, která je nezbytně nutná pro plnohodnotný život po ukončení léčby. V České ani Slovenské republice $\mathrm{v}$ cílových regionech dosud tato sít' pracovišt' neexistuje. $Z$ tohoto důvodu byl také vybrán vedoucí partner projektu Nadační fond dětské onkologie KRTEK, který se již 12 let zabývá problematikou onkologického onemocnění. Tento nadační fond se svojí činností zaměřuje na podporu komplexní péče o onkologicky nemocné děti absolvující léčbu na Klinice dětské onkologie Fakultní nemocnice v Brně, která je jedním ze dvou oficiálních center akreditovaných pro diagnostiku a léčbu nádorových onemocnění u dětí a mladých dospělých v ČR. Ve Slovenské republice bude partnerem projektu sdružení Rada mládeže Žilinského kraje. Toto sdružení je významnou organizací v oblasti vzdělávání a formování dětí, mládeže a dobrovolníků, vytváří podmínky pro pravidelnou zájmovou činnost dětí zdravých i postižených. Spolupracuje s ostatními Radami mládeže Trenčínského a Trnavského kraje, které spadají do regionů dopadu. Dalším partnerem na české straně je Fakulta tělesné kultury Univerzity Palackého v Olomouci, která se jako jediná v České republice zabývá aplikovanými pohybovými aktivitami pro osoby s postižením a dlouhodobým onemocněním se zaměřením na dětskou onkologii. Má vynikající výsledky na mezinárodní úrovni a je pro kvalitu projektu a pro realizaci pohybových aktivit, které jsou 
součástí zvyšování kvality života dětí s onkologickým onemocněním během léčby a po léčbě, odborným garantem a tudíž nezbytná.

\section{HLAVNÍ ČÁST}

Hlavním cílem projektu je vytvoření sítí organizací na úrovni neziskových organizací, školských a zdravotnických organizací a vysokých škol zabývajících se zvyšováním kvality života dětí s onkologickým onemocněním během léčby a po jejím ukončení. Bude vytvořen systém spolupráce na úrovni Nadačního fondu dětské onkologie (Česká republika), Univerzity Palackého v Olomouci (Česká republika) a sdruŽení Rada mládeže Žilinského kraje (Slovenská republika). Tyto organizace budou dále spolupracovat se sportovními, případně pedagogickými, sociálními a zdravotnickými fakultami (implementace do systému praxí a stáží), klinikami dětské onkologie fakultních nemocnic, lékařských fakult (oblast zdravotní, akademická), speciálně poradenskými centry, stř̌edními zdravotnickými školami (oblast školská) a klinickými psychology. Na základě vytvoření sítě dojde ke komplexní péči o děti s onkologickým onemocněním a jejich sourozence a rodiče, ke zvyšování kvality života těchto dětí a jejich rodin, k jejich lepšímu zpětnému začlenění do běžného života, a v neposlední řadě i lepšímu transferu teorie aplikovaných pohybových aktivit (pohybových aktivit jako prostředku socializace osob se speciálními potřebami, včetně dětí dlouhodobě nemocných a v léčení) do praxe. Pomocí česko-slovenské spolupráce chceme vytvořit unikátní systém výměnných pobytových programů, kde se budou děti s onkologickým onemocněním, jejich rodiče i sourozenci z České a Slovenské republiky společně setkávat a absolvovat cílené programy na zkvalitnění jejich života pod odborným vedením. Touto spoluprací očekáváme především výměnu zkušeností z českého i slovenského prostředí, poznávání tradic a kultur pohraničí a především lepší tvorbu sociálních kontaktů, které jsou potřebné pro zvýšení psychické pohody léčených dětí a jejich rodin. Školení pedagogických, zdravotnických pracovníků a dalších pracovníků v oblasti volného času, sociálních služeb aj bude realizováno formou jednodenních a vícedenních školení. Tato 
školení jsou nezbytnou součástí udržitelnosti vytvořených sítí a jsou primární přidanou hodnotou celého projektu. Slouží ke sdílení zkušeností, informací a nejnovějších poznatků při respektování pozitivního dopadu projektu na cílovou skupinu v príhraničních vybraných regionech. Následné další specifické cíle projektu jsou dalšími aktivitami, které budou sloužit k podpoře sítě při jejich aktivitách a realizovaných programech. Zároveň budou nutné pro celkovou udržitelnost projektu a optimalizaci vynaložených nákladů.

Specifické cíle jsou nezbytné zejména pro optimální dopad vytvořených sítí a udržitelnost projektu.

\section{Specifické cíle projektu:}

1. Vytvořit systém základní podpory pro vytvoření partnerské sítě dojde k vytvoření partnerské sítě organizací umožňující lepší spolupráci v problematice onkologického onemocnění.

2. Realizace pohybových programů pro děti s onkologickým onemocněním během léčby a po léčbě - díky odbornému vedení těchto programů bude docházet ke zvyšování kvality života dětí s onkologickým onemocněním, jejich sourozenců a rodičů. Dojde také k prohloubení spolupráce partnerských organizací.

3. Školenípedagogických, zdravotnických a dalších pracovníků-pracovníci těchto oblastí získají odbornou způsobilost pro práci s cílovými skupinami. Výrazným způsobem se podpoří udržitelnost projektu.

4. Monitoring současného stavu v oblasti kvality života dětí s onkologickým onemocněním, jejich rodin a profesionálů pracujících v této oblasti - pomocí zjištěných informací se bude daná problematika optimálně a efektivně řešit a rozvíjet.

5. Vytvoření metodických materiálů pro realizaci hlavního cílů projektu - materiály zvýší odbornou orientaci v dané problematice široké veřejnosti.

6. Vytváření podkladů pro tvorbu strategických dokumentů a jejich implementaci na komunální úrovni v cílových regionech - zvýší podporu pro sít' pracovišt' a její udržitelnost v oblasti měst a krajů. 
7. Odborná konference - zajistí informovanost laické i odborné veřejnosti o dané problematice.

\section{ZÁV̌̌R}

Motto projektu: „Práce není jakákoliv činnost, ale jen ta, která mění svět.“" (Václav Bělohradský)

Informace o projektu:

- Realizace projektu: 1. 8. 2012 - 28. 2. 2015.

- Cílové kraje:

- ČR - Jihomoravský, Zlínský, Moravskoslezský.

- SR - Žilinský, Trnavský, Trenčínský.

- Hlavní řešitel projektu: Nadační fond dětské onkologie KRTEK.

- Partner projektu ČR: Katedra aplikovaných pohybových aktivit, FTK UP.

- Řešitel projektu za FTK UP: Mgr. Tomáš Vyhlídal, vyhlidal.apa@upol.cz, 733690596.

- Partner projektu SR: Rada mládeže Žilinského kraje.

\section{KONTAKT:}

Mgr. Tomáš Vyhlídal, vyhlidal.apa@upol.cz 